\title{
TINJAUAN PUSTAKA \\ PENCEGAHAN PENYAKIT DEGENERATIF DAN PENGATURAN MAKANAN DALAM KAJIAN KEDOKTERAN DAN AL-QURAN
}

\author{
Hardisman \\ Bagian Pendidikan Kedokteran (BPK) \\ dan Bagian Anestesiologi, Fakultas Kedokteran Universitas Andalas \\ Email: hardisman@fk.unand.ac.id
}

\begin{abstract}
Abstrak
Proses kemunduran fungsi tubuh atau degeratif merupakan proses alamiah tubuh manusia yang harus diperhatikan setiap orang [QS Al-Hajj (22):5, Yaasin (36):68]. Dalam proses tersebut seseorang akan dapat terkena berbagai penyakit kronik seperti penyakit kardiovaskuler, obesitas dan diabetes melitus. Meskipun demikian, dengan gaya hidup yang baik dan pengaturan makanan, resiko penyakit-penyakit tersebut dapat dicegah. Salah satu resiko dalam terjadinya penyakit kardiovaskuler adalah hipekoleterolemia dan dislipidemia. Dua kondisi ini dapat disebabkan asupan makanan yang mengandung lemak dan kolesterol yang berlebihan. Serta, ketidakseimbangan asupan karbohidrat, lemak, dan serat juga menjadi resiko terjadinya obesitas dan diabetes melitus. Semua kajian ilmu kedokteran ini merupakan bukti bahwa peranan pengaturan makanan sangat penting, sebagaimana yang diterangkan dlama Al-Quran [Al-Baqarah (2):168172, Al-Isra' (17):26-27 and Al-A'raf (7):31].
\end{abstract}

Kata Kunci: Penyakit degeratif, pengaturan makanan, dan Al-Quran.

\section{Abstract}

Degenerative is a natural process in human life that every body should aware [QS Al-Hajj (22):5, Yaasin (36):68]. During the process, someone can get chronic degenerative diseases such as cardiovascular, obesity and diabetes mellitus. However, by having good life style and diet regulation, the risk of the diseases can be prevented. In medical perspective, one of the risks of the cardiovascular diseases is hypercholesterolemia and dislipidemia. These two conditions can be caused by excessive intake of lipid and cholesterol. Meanwhile, imbalance intake of carbohydrate, lipid and food fibre also becomes risk of obesity and diabetes mellitus. All of these medical analysis become evidences of the rule of diet regulation which has been written in the Quran [Al-Baqarah (2):168-172, Al-Isra' (17):26-27 and Al-A'raf (7):31].

Key Words: Degenerative Diseases, diet regulation, and The Qur'an. 


\section{Pendahuluan}

Dalam al-Qur`an dijelaskan bahwa dalam proses kehidupan manusia suatu saat ini akan kembali pada bentuk yang lemah [Al-Hajj (22):5 dan Yaasin (36):68], ${ }^{(1)}$ yang dalam ilmu kedokteran lebih dikenal dengan proses degenerasi. Keadaan yang buruk dari proses degenerasi ini adalah munculnya berbagai penyakit degeneratif atau penyakit-penyakit ketuaan. Namun dalam al-Qur`an juga disebutkan bahwa hanya sebagian orang yang jatuh pada titik terlemah ini, atau tidak semua orang bisa menderita penyakit degeneratif. Banyak faktor yang dapat berperan terhadap munculnya berbagai penyakit ini, pengaturan makanan adalah salah satunya. ${ }^{(2,3)}$

Pada tulisan ini akan dijelaskan secara singkat bagaimanakah munculnya penyakit degeneratif dan peranan zat gizi terhadap penyakitpenyakit tersebut dalam kajian AlQur`an dan kedokteran modern. Karena penyakit degenratif itu cukup banyak, pembahasan singkat ini hanya dibatasi pada penyakit kardiovaskuler, obesitas dan diabetes mellitus.

\section{Penyakit Degeneratif}

Penyakit degeneratif secara sederhana dapat dikatakan sebagi penyakit pada umur tua. Sesuai dengan arti secara bahasa, kata degeneratif dalam bahasa Indonesia merupakan adobsi langsung dari kata 'degenerative' dalam bahasa ingrgris, yang berarti bersifat merosot atau kemunduran dan mengalami perobahanperobahan yang terjadi pada umur tua. Penyakit-penyakit kronis tersebut diantaranya adalah penyakit jantung koroner (PJK), diabetes mellitus, stroke, sirosis hepatis, batu empedu dan lainlainnya. Penyakit-penyakit tersebut kadang tidak berdiri sendiri, namun suatu penyakit dapat juga menimbulkan atau menjadi resiko terjadinya penyakit lain. $^{(2,3)}$

Al-Qur'an telah menerangkan tentang degeneratif merupakan proses yang dilalui oleh sebagian manusia, seperti yang diterangkan dalam surah Al-Hajj (22):5 dan Yaasin (36):68. ${ }^{(1)}$

"Hai manusia, jika kamu dalam keraguan tentang kebangkitan (dari kubur), Maka (ketahuilah) Sesungguhnya Kami telah menjadikan kamu dari tanah, kemudian dari setetes mani, kemudian dari segumpal darah, kemudian dari segumpal daging yang sempurna kejadiannya dan yang tidak sempurna, agar Kami jelaskan kepada kamu dan Kami tetapkan dalam rahim, apa yang Kami kehendaki sampai waktu yang sudah ditentukan, kemudian Kami keluarkan kamu sebagai bayi, kemudian (dengan berangsur- angsur) kamu sampailah kepada kedewasaan, dan di antara kamu ada yang diwafatkan dan (adapula) di antara kamu yang dipanjangkan umurnya sampai pikun, supaya Dia tidak mengetahui lagi sesuatupun yang dahulunya telah diketahuinya. dan kamu Lihat bumi ini kering, kemudian apabila telah Kami turunkan air di atasnya, hiduplah bumi itu dan suburlah dan menumbuhkan berbagai macam tumbuh-tumbuhan yang indah." [surah Al-Hajj (22):5].

"Barangsiapa yang Kami panjangkan umurnya niscaya Kami kembalikan Dia kepada kejadian(nya), maka Apakah mereka tidak memikirkan?" [Yaasin (36):68].

Dalam ayat-ayat di atas dijelaskan bahwa manusia semakin tua setelah melewati puncak kedewasaan maka ia akan kembali kepada kejadiannya. Manusia akan menjadi lemah dan mengalami kemunduran dan 
dalam ilmu kedokteran saat ini dikenal dengan proses degeneratif.

Proses degeneratif ini tidak hanya bertujuan untuk meningkatkan keimanan dan mengagungkan kebesaran Tuhan (tujuan tahuid) [surah Al-Hajj (22):5], namun juga bertujuan untuk stimulasi agar manusia mau berfikir dan menggali aspek yang ada dibalik itu. Dengan kata lain, menurut Qur`an proses degeneratif yang ada juga harus digali menurut ilmu pengetahuan [Yaasin (36):68]. ${ }^{(1)}$

Ayat-ayat tersebut juga menegaskan bahwa proses degeneratif ini adalah proses alamiah yang akan dilalui oleh manusia dan kelanjutan proses pertumbuhan dan perkembangan manusia. Namun Allah SWT memberikan contoh, hanya sebagian manusia saja yang jatuh kepada pikun (salah satu bentuk degeneratif), yang tentunya sinyal-sinyal ini harus digali dengan ayat-ayat kauniyah (ilmu kedokteran) siapa yang bisa jatuh kedalam degeneratif tersebut. ${ }^{(1)}$ Oleh karena, stimulasi itu menjadi alasan kuat dalam Islam untuk mengkaji proses dan penyakit-penyakit degeneratif.

Dalam kajian ilmu kedokteran, proses terjadinya penyakit degeneratif berlangsung dalam waktu yang lama atau kronis. Penyakit degeneratif yang muncul pada seseorang adalah akibat kesalahan gaya hidup, aktifitas dan pola makannya yang terjadi 15-25 tahun sebelumnya. ${ }^{(2-4)}$ Penyakit degeneratif terjadi akibat berbagai faktor baik faktor yang irreversibel ataupun faktorfaktor reversibel. Faktor-faktor irreversibel yang berpengaruh adalah usia jenis kelamin dan genetik. Namun munculnya penyakit ini lebih banyak dipengaruhi oleh faktor-faktor yang reversibel atau yang dapat dicegah, seperti dislipidemia, merokok, rendah konsumsi serat, stress dan kurang gerak fisik. ${ }^{(2-5)}$

Dengan melihat kepada faktorfaktor resiko ini jelas terlihat bahwa peranan zat gizi sangat penting dalam terjadinya penyakit degeneratif, seperti kurang konsumsi serat makanan dan juga ketidakteraturan pola asupan makanan. Kesalahan pola makan ini dalam waktu relatif lama dapat menimbulkan hiperkolesterolemia dan hiperlipidemia. (2-5) Selengkapanya, pada bagian ini kita lihat bagaimana peranan makanan atau pola konsumsi zat gizi dengan timbulnya penyakitpenyakit degeneratif tersebut. Seperti yang disebutkan diawal, bahwa penyakit degeneratif itu cukup banyak, namun pada buku kecil ini hanya akan dijelaskan penyakit degeneratif yang sering terjadi di masyarakat. Penyakitpenyakit yang dibahas pada tulisan sini adalah penyakit jantung dan pembuluh darah (kardiovaskuler), kegemukan (obesitas) dan diabetes melitus.

\section{Penyakit Kardiovaskuler dan zat Gizi Penyakit-penyakit}

kardiovaskuler sering ditemukan di masyarakat. Penyakit-penyakit tersebut erat kaitannya dengan peningkatan kadar lemak dan kolestrol darah. Peningkatan kadar lemak dan kolesterol darah merupakan manifestasi dari kesalahan pola konsumsi gizi, misalnya tingginya konsumsi makanan yang mengandung asam lemak jenuh, gula murni dan kolestrol. Penyakit-penyakit tersebut diantaranya penyakit jantung koroner, sindroma angina pectoris dan hipertensi. ${ }^{(2,5,6)}$

Salah satu penyakit
kardiovaskuler degeneratif adalah
penyakit jantung koroner yang
disebabkan oleh proses aterosklerosis
atau pengerasan dan kekakuan pada


pembuluh darah jantung (arteri yang mengandung lemak jenuh pada koroner). penyakit jantung koroner makanan. ${ }^{(2,5-9)}$

sangat berbahaya karena dapat Konsekuensi lain akibat menyebabkan kematian mendadak dan terjadinya aterosklerosis adalah dapat juga menyerang usia produktif. hipertensi atau secara sederhana dapat Namun resiko penyakit ini meningkat dikatakan peningkatan tekanan darah. sejalan dengan peningkatan umur. Dimana secara klinis, seseorang Manifestasi atau gejala dan tanda-tanda dinyatakan hipertensi bila tekanan darah penyakit jantung koroner karena seseorang melebihi dari 140/90mmHg terjadinya ketidakseimbangan (tekanan darah sistolik lebih dari kebutuhan oksigen otot jantung $140 \mathrm{mmHg}$ dan diastolik lebih dari (miokardium) dengan asupan dan $90 \mathrm{mmHg}){ }^{(5,7,8)}$ Ateroskleoris atau ketersediaan oksigen pada jaringan otot kekakuan dan sumbatan pada pembuluh tersebut. Hal ini terjadi karena darah di selurruh tubuh dapat terjadinya penyempitan atau mengakibatkan adanya tahan aliran penyumbatan pada ateri koroner akibat darah. Akibatnya dengan curah jantung aterosklerosis sehingga aliran darah dan volume aliran darah yang sama menjadi sangat berkurang ke jaringan dengan pembuluh darah yang kaku akan otot jantung yang disebut dengan terjadi peningkatan tekanan. Penyakit iskemia. ${ }^{(2,5-7)}$

\section{Berdasarkan}

terjadinya aterosklerosis ini dapat dilihat bahwa peranan pengaturan pola makan dan asupan jenis zat gizi sangat berperan. Framingham study, suatu penelitian yang sangat terkenal dalam ilmu kedokteran dalam bidang gizi dan penyakit degeneratif menerangkan bahwa banyak faktor yang dapat mempercepat dan meningkatkan resiko terjadinya aterosklerosis. Faktor-faktor tersebut adalah obesitas, hiperlipidemia atau dislipidemia, merokok, diabetes melitus, emosi, kurang aktifitas fisik, genetik, umur, jenis kelamin dan kepribadian tipe A. $^{(2,5-8)}$

Diantara resiko tersebut, hiperlipidemia sangat erat kaitannya dengan pola konsumsi zat gizi. Hiperlipidemia dan dislipidemia, atau peningkatan dan ketidakseimbangan lemak darah dalam tubuh terjadi akibat lanjut dari peningkatan kadar lemak (trigliserida) darah, kolesterol total peningkatan LDL-kolesterol dan penururan HDL. Peningkatan dan gangguan komposisi lemak darah ini dapat terjadi akibat kelebiha konsumsi kolesterol dan lemak ini sangat perlu diwaspadai karena dapat meneimbulkan berbagai penyakit pada organ lain, seperti gangguan ginjal, mata dan otak. ${ }^{(5,7)}$

Dengan melihat berbagai macam mekanisme tersebut diatas, dapat dilihat bahwa untuk mencegah timbulnya berbagai macam penyakit kardiovaskuler, kadar lemak dan kolestrol darah haruslah tetap normal. Untuk mengatur agar kadar kolesterol darah tetap dalam kedaan normal perlu pengaturan pola dan jenis makanan secara baik dan optimal. ${ }^{(2,7,9)}$

Prinsip-prinsip diatas secara jelas menegaskan bahwa penguturan pola dan jenis makanan sangat dibutuhkan dalam pencegahan penyakit-penyakit degeneratif kardiovaskuler. Penerapan prinsip diatas dapat dilakukan dengan cara mengurangi konsumsi lemak yang mengandung asam lamak jenuh serta kolestrol. Cara lain adalah dengan cara meningkatkan konsumsi asam lemak esensial dari asam lemak tak jenuh seperti asam lemak omega-3. Konsumsi asam lemak esensial yang optimal dapat meningkatkan kadar HDL-kolestrol 
darah dan menurunkan LDL-kolestrol. Obesitas dan zat Gizi

Sehingga akhirnya seperti yang dijelaskan pada berbagai mekanisme yang disebutkan sebelumnya, dengan rendahnya LDL dan optimalnya kadar HDL dapat menurunkan resiko terjadinya aterosklerosis. Pada khirnya akan dapat mencegah timbulnya penyakit jantung koroner dan hipertensi. ${ }^{(2,5,7-9)}$

Selain itu diupayakan agar konsumsi kalori atau karbohidrat harus sesuai dengan kebutuhan tubuh, aktifitas sehari-hari dan kedaan pertumbuhan. Kalori yang dikonsumsi haruslah optimal dalam mencukupi kebutuhan kalori perhari dan tidak boleh berlebihan. Bila konsumsi karbohidrat berlebihan maka tubuh akan menyimpannya dalam bentuk glikogen dan lemak sebagai cadangan kalori. Namun, karena penyimpanan dalam bentuk glikogen terbatas, bila konsumsi kalori sangat berlebihan maka akan disimpan dalam lemak (trigliserida) dengan tidak terbatas. Bila hal ini terus berlanjut maka akan dapat menimbulkan kegemukan atau obesitas. Obesitas akhirnya juga bereiko terhadap timbulnya penyakit jantung koroner, angina pectoris dan hipertensi. Melalui mekanisme biokimia dalam tubuh, obesitas dapat menurunkan kadar HDL dan meningkatkan LDL-kolestrol, sehingga akhirnya meningkatkan resiko terjadinya aterosklerosis yang merupakan proses awal terjadinya berbagai penyakit degeneratif kardiovaskuler tersebut. Oleh karena itu pengaturan diet pola makan lainnya yang harus dilakukan dalam mencegah penyakit degeneratif kardiovaskuler ini adalah megontrol asupan kalori atau karbohidrat. ${ }^{(2,5,7,8)}$

Obesitas atau yang dikenal dalam bahasa sehari-sehari dikenal dengan kegemukan dialami oleh hampir oleh seluruh kelompok masyarakat dan setiap zaman, mulai dari zaman dahulu kala hingga zaman moderen saat ini. Akan tetapi, pada masa dan kelompok masyarakat tertentu, meskipun kegemukan cukup sering ditemukan, ia dianggap sebagai suatu hal yang wajar saja dan bukan dirasakan sebagai suatu yang mengganggu apalagi sebagi suatu penyakit. Bahkan pada sebagian kelompok masyarakat itu atau budaya tertentu, obesitas menjadi suatu kebanggaan karena dikaitkan dengan kesejahteraan dan tingkat ekonomi. Namun seiring dengan perkembangan ilmu pengetahuan dan informasi, pengetahuan masyarakat tentang kesehatan pun semakin meningkat maka saat ini hamper semua kelompok masyarakat mulai menyadari bahwa obesitas merupakan suatu kelainan degeneratif yang berbahaya dan dapat beresiko terhadap timbulnya penyakit lain. ${ }^{(10-12)}$

Dalam ilmu gizi dan kedokteran, prinsip yang digunakan untuk menentukan apakah seseorang mengalami obesitas atau tidak adalah dengan mengukur kadar lemak tubuh. Untuk menentukan kadar lemak tubuh ini dilakukan dengan cara mengukur indeks masa tubuh (IMT) atau mengukur langsung tebal lemak dibawah kulit. Pengukuran indeks masa tubuh digunakan sebagai cara sederhana dalam menentukan lemak tubuh pada usia mulai dari 18 tahun. Secara matematis IMT adalah hasil perhitungan dari berat badan (BB) dengan tinggi badan (TB) dalam satuan 
meter yang dikuadratkan, seperti yang terlihat pada diagram 1. Seseorang dikatakan obesitas berdasarkan pengukuran IMT bila IMT-nya lebih dari $30 \mathrm{~kg} / \mathrm{M}^{2}$. ${ }^{(10,11)}$

$$
\text { IMT }=\frac{\text { BB }}{(\mathrm{TB})^{2}} \quad \begin{aligned}
& \frac{\text { Satuannya: }}{\text { BB dalam Kg }} \\
& \text { TB dalam meter }(\mathrm{m})
\end{aligned}
$$

\section{Diagram 1: Formula menentukan Obesitas} dan Status Gizi

Sumber: Diambil dari berbagai kepustakaan. ${ }^{(3,4,10-12)}$

Selanjutnya sebagai perbandingan dapat juga dilihat keadaan obesitas dan status gizi lain berdasarkan pengukuran IMT. Selengkapnya gambaran status gizi ini dapat dilihat pada tabel 1.

Tabel 1. Standar Nilai Indeks Masa Tubuh (IMT)

\begin{tabular}{|l|l|}
\hline \multicolumn{1}{|c|}{ Nilai IMT } & \multicolumn{1}{c|}{ Status Gizi } \\
\hline$<16$ & Malnutrisi buruk \\
$16-17$ & Malnutrisi sedang \\
$>17-19$ & Malnutrisi ringan \\
$20-25$ & Normal \\
$>25-30$ & Berat badan lebih \\
& (overweight) \\
$>30-40$ & Obesitas \\
$>40$ & Obesitas berat \\
\hline
\end{tabular}

Sumber: Diambil dari berbagai kepustakaan. $^{(3,4,10-12)}$

Obesitas yang dialami seseorang dapat berdampak pada gangguan fungsi tubuh atau resiko medis dan juga psikososialnya. Pada zaman sekarang ini, masyarakat merasakan adanya dampak psikososial dari obesitas yang dialaminya. Resiko psikososial yang dirasakan adalah adanya hambatan aktifitas fisik dan interaksi sosial dengan masyarakat akibat munculnya perasaan kurang percaya diri. Namun sayangnya masyarakat masih belum menyadari akan dampak atau resiko medis yang ditimbulkannya. ${ }^{(10-13)}$
Untuk mengetahui peranan gizi atau pengaturan pola dan jenis makanan dalam mencegah terjadinya obesitas, maka perlu dijelaskan secara lengkap faktor-faktor yang berperan dalam terjadinya obesitas. Faktor-faktor tersebut adalah faktor genetik, hormonal dan faktor makanan atau zat gizi. Faktor-faktor ini secara bersamasama berperan dalam menimbulkan obesitas. Namun faktor genetik hanyalah merupakan faktor pendahulu atau presdisposisi yang artinya seseorang tidak dapat menjadi obesitas bila tidak ada peranan faktor lain. Begitu juga halnya dengan faktor hormonal, faktor ini hanya berperan dalam proses terjadinya obesitas bila faktor-faktor lain ada terutama faktor asupan makanan. Dengan demikian jelas terlihat bahwa pola dan jenis zat gizi yang dikonsumsi sangat berperan penting. Konsumsi lemak dan karbohidrat yang sangat berebihan merupakan yang harus diwaspadai. ${ }^{(10-13)}$ Melihat besarnya peran makanan dalam timbulnya obesitas ini, maka pengobatan dan penatalaksanaan penderita obesitas terutama adalah dengan tidak menggunakan obat-obatan atau non-farmakologis, yang terdiri dari pengaturan optimal aktifitas jasmani dan pengaturan pola dan jenis makanan. Pengaturan makanan adalah berupaya mencapai berat badan ideal dengan mengupayakan indeks masa tubuh dalam batas normal. Sedangkan pada obesitas yang disertai dengan penyakit lain seperti penyakit jantung dan diabetes mellitus, pengaturan makanan dan asupan gizinya harus disesuaikan dengan kondisi penyakitnya tersebut. ${ }^{(10)}$

\section{Diabetes dan Zat Gizi}

Diabetes melitus secara umum dimasyarakat dikenal dengan penyakit gula. Hal ini tidaklah salah karena diabetes mellitus muncul akibat 
kelebihan kadar gula (glukosa) darah.

Secara medis seseorang baru dikatakan menderita diabetes melitus bila pemeriksaan kadar gula darah puasa dan dua jam setelah makan keduaduanya daiatas normal yang disertai dengan adanya gejala klinis minimal. ${ }^{(14,15)}$

Tipe dan klasifikasi diabetes melitus ini bermacam-macam, seperti yang dikeluarkan oleh PERKENI (Perkumpulan Endokrinologi Indonesia) dan WHO. Akan tetapi, selain dari kerusakan absolut pada produksi akibat kerusakan sel-sel beta pankreas, diabetes melitus ini juga dicetuskan oleh ketidakseimbangan pola asupan kalori, aktifitas dan kebutuhan tubuh. ${ }^{(14)}$

Oleh karena itu dapat dikatakan bahwa pola konsumsi zat gizi sangat berperan penting dalam menimbulkan gejala dan gangguan klinis pada penyakit diabetes. Hal ini dibuktikan dengan adanya peningkatan kasus diabetes pada berbagai negara-negara maju dan berkembang termasuk Indonesia, terutama pada masa peralihan peningkatan status ekonomi.

Angka kejadian (prevalensi) diabetes melitus di Indonesia cukup tinggi. Beberapa kepustakaan menyebutkan diabetes melitus terjadi sekitar 1,5-2,3\% pada penduduk usia diatas 15 tahun. Angka kejadian ini selalu meningkat setiap tahunnya pada beberapa daerah dan kota di Indonesia. Bahkan diprediksikan semua penyakit degeneratif di Indonesia akan selalu terjadi peningkatan, dan diabetes melitus adalah salah satunya yang meningkat cukup cepat. Meningkatnya angka kejadian diabetes melitus di beberapa daerah di Indonesia adalah akibat perubahan kemakmuran daerah tersebut yang dikuti dengan perubahan pola makan dan gaya hidup. ${ }^{(13,14)}$
Berdasarkan banyaknya laporan diabetes melitus ini di Indonesia diprediksikan dengan peningkatan penduduk sebesar $40 \%$ dalam waktu tiga puluh tahun, akan terjadi peningkatan jumlah kasus diabetes melitus sekitar 80-130\%. Hal ini disebabkan tingginya berbagai resiko untuk terjadinya penyakit ini. Faktorfaktor tersebut termasuk faktor demografi, gaya hidup dan pola makan serta berobahnya distribusi penyakit. ${ }^{(14,15)}$ Faktor demografi yang berperan dalam peningkatan jumlah penduduk adalah urbanisasi dan makin banyaknya penduduk yang berusia tua. Peubahan gaya hidup masyarakat saat ini juga sangat berperan. Dengan terjadinya peningkatan ekonomi, masyarakat ingin selalu senang, mengurangi aktifitas fisik dan pola asupan makanan pun tidak seimbang. Disamping itu dengan adanya peningkatan ekonomi, pendidikan dan kesadaran masyarakat maka kejadian penyakit infeksi dan kurang gizi makin berkurang. Disamping itu kesadaran masyarakat pun semakin meningkat untuk mau melakukan konsultasi, kontrol kesehatan dan berobat ke rumah sakit sehinnga angka kejadian yang tercatat cukup tinggi. ${ }^{(14,16)}$

Meskipun peningkatan angka kejadian diabetes melitus dipengaruhi oleh faktor-faktor lain, namun peningkatan ini secara bermakna sangat dipengaruhi oleh faktor pola konsumsi zat gizi dan gaya hidup. Oleh karena itu perlu dilakukan upaya-upaya pencegahan dengaan merubah kabiasaan jelek pada pola makan dan kurang aktifitas pada seseorang.

Ada alasan kuat mengapa diabetes harus benar-benar dicegah karena dapat berakibat fatal bagi fungsi sistim dan organ tubuh lainnya. 
Diabetes perlu diwaspadai terutama pada seseorang yang telah mempunayai faktor predisposisi genetik agar kemungkinan diabetes pada dirinya tidak bermanifestasi menimbulkan gejala klinis. ${ }^{(16)}$

\section{Perspektif Kajian Al-Qur`an}

Setelah kita melihat proses sebagian kecil penyakit degeneratif dari penyakit jantung dan pembuluh darah (kardiovaskuler), obesitas dan penyakit gula (diabetes melitus), ternyata sebagian faktor-faktor degenratif ini tidak dapat dihindari. Hal ini dibuktikan dengan main meningkatnya jumlah kasus penyakit-penyakit degeneratif tersebut. Dengan demikian kita menyadari bahwa proses degenerasi merupakan proses yang tidak dapat dihindari secara mutlak. Dalam perspektif kajian Islam, Al-Qur`an juga telah menjelaskan bahwa proses degeneratif itu merupakan proses yang sejalan dengan pertambahan umur. Secara tegas Allah menjelaskan dalam surah Ar-Ruum (30):54. ${ }^{(1)}$

"Allah, Dialah yang menciptakan kamu dari keadaan lemah, kemudian

Dia menjadikan (kamu) sesudah Keadaan lemah itu menjadi kuat, kemudian Dia menjadikan (kamu) sesudah kuat itu lemah (kembali) dan beruban. Dia menciptakan apa yang dikehendaki-Nya dan Dialah yang Maha mengetahui lagi Maha Kuasa." [Ar-Ruum (30):54].

Namun, Al-Qur’an juga menjelaskan bahwa meskipun proses degenerasi itu adalah sesuatu proses alamiah, tetapi hanya sebagian kecil saja manusia yang sampai jatuh pada titik terlemah. Sebagaimana yang di nyatakan secara tegas dalam surah AlHajj (22):5, yang dalam ayat ini dicontohkan adalah pikun atau dimensia. Dalam makna luas, sesuai dengan bukti-bukti kajian ilmu kedokteran makna titik terlemah itu dapat diartikan sebagai jatuhnya seseorang kepada penyakit-penyakit degneratif itu. Dengan demikian dapat dikatakan bahwa penyakit-penyakit degneratif itu dapat dicegah, dan diantara usaha yang dapat dilakukan dalam pencegahan itu adalah pengaturan pola konsumsi dan jenis makanan atau zat gizi.

Konsep pemilihan dan pengaturan jenis dan pola makanan yang diatur dalam Al-Qur`an seperti yang telah diuraikan pada bagian sebelumnya bahwa makanan yang diperbolehkan untuk manusia adalah makanan yang halal dan baik [AlQur'an surah Al-Baqarah (2):168 dan 172, Al-Ma idah (5):4 dan Al-A'raf (7):157].

"Hai sekalian manusia, makanlah yang halal lagi baik dari apa yang terdapat di bumi, dan janganlah kamu mengikuti langkah-langkah syaitan; karena Sesungguhnya syaitan itu adalah musuh yang nyata bagimu." [Al-Baqarah (2):168].

"Hai orang-orang yang beriman, makanlah di antara rezki yang baikbaik yang Kami berikan kepadamu dan bersyukurlah kepada Allah, jika benarbenar kepada-Nya kamu menyembah." [Al-Baqarah (2):168].

Kata-kata baik (tayyiban) dalam arti luas adalah jenis dan pola konsumsi makanan yang sesuai dengan kebutuhan tubuh. Disamping itu, ayat-ayat diatas juga meemberikan sinyal bahwa makanan yang dikonsumsi sangat berpengaruh besar terhadap kesehatan fisik dan jiwa. Hal ini juga pernah dijelaskan oleh Hamka dalam tafsir AlAzharnya dalam menerangkan makna 
ayat-ayat pengaturan makanan dalam Tetapi pada penghujung surah AlAl-Qur`an, bahwa makanan sangat Baqarah (2):173 dijelaskan bahwa pada berpengaruh terhadap kesehatan, sikap keadaan darurat atau 'terpaksa' zat-zat hidup, jiwa, kehalusan atau kekasaran atau bahan makanan tersebut menjadi budi seseorang.

Makanan baik-baik senantiasa dianugerahkan oleh Allah SWT untuk manusia dalam bentuk tumbuhtumbuhan, buah-buahan yang beraneka ragam dan binatang ternak yang beraneka ragam pula [Al-Qur'an surah Al-An'am (6):99, Faathir (35):27-28 dan Al-Hajj (22): 30], serta telah diciptakan juga berbagai macam hewan lainnya untuk kebutuhan manusia [surah Al-An'am (6):142-146, An-Nahl (16):5-8 dan 80, Yaasin (36):71-73 dan Al-Mu`min (40):79-80] seperti yang dijelaskan pada bagian sebelum nya. Disamping itu telah dihalalkan bagi manusia sbahagian dari susu hewan yang mendatangkan manfaat bagi manusia [surah An-Nahl (16):63 dan Al-Mu'munun (23):21]. Semua makanan yang dihalalkan bagi manusia itu bila ditelaah lebih lanjut dengan bukti-bukti ilmu kedokteran dan ilmu gizi terbukti bermanfaat besar bagi kesehatan manusia. Makanan tersebut mengandung zat-zat gizi yang dibutuhkan oleh tubuh, dan bila dikonsumsi secar optimal akan mendatangkan kesehatan yang optimal pula.

Dalam surah Al-Ma idah (5):3 dan Al-Baqarah (2):173 juga dijelaskan bahwa pengharaman makanan tertentu seperti bangkai, darah, daging babi dan hewan yang disembelih bukan dengan nama Allah. Bentuk-bentuk makanan ini adalah sebagian contoh makananmakanan yang tidak baik (tayyiban). Kan tetapi sampai saat ini, memang ilmu pengetahuan terutama ilmu kedokteran belum mampu mebuktikan secara sempurna apa hikmah dibalik pengharaman semua makanan tersebut. diboleh-kan dengan sarat hanya sekedarnya. ${ }^{(1)}$

"Sesungguhnya Allah hanya mengharamkan bagimu bangkai, darah, daging babi, dan binatang yang (ketika disembelih) disebut (nama) selain Allah. tetapi Barangsiapa dalam Keadaan terpaksa (memakannya) sedang Dia tidak menginginkannya dan tidak (pula) melampaui batas, Maka tidak ada dosa baginya. Sesungguhnya Allah Maha Pengampun lagi Maha Penyayang."

[Al-Baqarah (2):173].

Makna keterpaksaan pada ayat ini adalah bila seseorang mengkonsumsi makanan tersebut karena tidak ada lagi makanan lain, sehingga kalau ia tidak memakan makanan tersebut bisa kelaparan, jatuh sakit dan bahkan kematian. Artinya keringanan atau rukhsah yang dibolehkan untuk mengkonsumsi makanan yang diharamkan adalah semata-mata untuk memperthankan nyawa, namun dalam memenuhi kebutuhan darurat ini tidak boleh berlebih-lebihan. Dapat dilihat disini bahwa Al-Qur’an menegaskan apa-apa bahan makanan yang diharamkan, akan tetapi secara tegas pula bila kebutuhan yang mendesak bahan-bahan makanan tersebut dihalalkan dikonsumsi sekedarnya karena dilarang pula menjatuhkan diri kedalam kebinasaan. Sebagaimana yang dijelaskan dalam Al-Qur'an surah AnNahl (16):115-116. ${ }^{(1)}$

"Sesungguhnya Allah hanya mengharamkan atasmu (memakan) bangkai, darah, daging babi dan apa 
yang disembelih dengan menyebut nama selain Allah; tetapi Barangsiapa yang terpaksa memakannya dengan tidak Menganiaya dan tidak pula melampaui batas, Maka Sesungguhnya Allah Maha Pengampun lagi Maha Penyayang."

"Dan janganlah kamu mengatakan terhadap apa yang disebut-sebut oleh lidahmu secara Dusta "Ini halal dan ini haram", untuk mengada-adakan kebohongan terhadap Allah. Sesungguhnya orang-orang yang mengada-adakan kebohongan terhadap Allah Tiadalah beruntung. "

[An-Nahl (16):115-116].

Konsep pengaturan pola dan jenis makanan dalam Islam mengharuskah memipilih bahan makanan yang 'baik-baik.' Penilaian nyang baik-baik harus dipertimbangkan oleh akal dan ilmu pengetahuan yang berkembang pada zamannya. Pada saat ini, ilmu kedokteran dan gizi telah membuktikan kelebihan dan tidak seimbangnya konsumsi makanan atau zat gizi tertentu dapat menimbulkan berbagai penyakit degeneratif, seperti penyakit-penyakit kardiovaskuler, obesitas dan diabetes melitus. Pengaturan pola dan konsumsi makanan lebih lanjut juga diterangkan dalam AlQur`an surah Al-A'raf (7):31. ${ }^{(1)}$

"Hai anak Adam, pakailah pakaianmu yang indah di Setiap (memasuki) mesjid, Makan dan minumlah, dan janganlah berlebih-lebihan. Sesungguhnya Allah tidak menyukai orang-orang yang berlebih-lebihan." [Al-A'raf (7):31]

Ayat diatas menjelaskan bagaiman konsep Al-Qur'an dalam mengatur pola dan jenis makanan. Sesuatu hal yang mutlak dilakukan adalah agar jangan mengkonsumsi zat gizi atau makanan tertentu dengan berlebihan. Telah dibuktikan dlam ilmu kedokteran dan gizi bahwa kelebihan zat makanan tertentu dapat menjadi resiko timbulnya penyakit-penyakit degeneratif. Seperti yang telah dijelaskan sebelumnya, kelebihan konsumsi kalori dapat menjadi resiko terjadinya obesitas dan diabetes melitus. Kedua penyakit degenartif ini juga akan beresiko untuk timbulnya berbagai penyakit degeneratif lain terutama penyakit-penyakit kardiovaskuler.

Kelebihan makanan yang mengandung lemak dan kolestrol secara langsung juga dapat menyebabkan hiperlipidemia dan hipekolesterolemia. Gangguan keseimbangan lemak darah ini akhirnya beresiko terhadap timbulnya penyakit-penyakit degeneratif terutama penyakit-penyakit kardiovaskuler dan perlemakan hati.

Inilah konsep Al-Qur`an tentang pengaturan pola dan jenis makanan, yakni agar tidak berlebih-lebihan. Berlebih-lebihan dalam mengkonsumsi makanan tertentu telah terbukti berdampak buruk bagi kesehatan dengan timbulnya berbagai penyakit degeneratif. Disamping itu ajaran Islam yang diterangkan dalam Al-Qur`an tentang pengaturan makanan ini bukan hanya untuk tujuan kesehatan jasmani, tetapi juga untuk tujuan aqidah dan syari'ah atau peribadatan kepada Allah SWT. Sebagaimana yang diterangkan bahwa "Allah tidak menyukai orang yang berlebih-lebihan [Al-A'raf (7):31]." Secara implisit ayat ini juga bermakna bahwa orang-orang yang yakin akan kebenaran dari Allah SWT dan mau mematuhi perintah-Nya akan mau dan mampu meninggalkan perbuatan boros atau berlebih-lebihan termasuk dalam mengkonsumsi makanan. Sehingga dalam perbuatannya sehari-hari senantiasa sesuai dengan yang diatur dalam Al-Qur`an. 
Lebih luas, Allah SWT benarbenar melarang secara tegas penggunaan harta secara berlebihlebihan, tentunya termasuk didalanya konsumsi makanan. Sebagai-mana yang dijelaskan dalam surah Al-Isra' (17):26.

"Dan berikanlah kepada keluargakeluarga yang dekat akan haknya, kepada orang miskin dan orang yang dalam perjalanan dan janganlah kamu menghambur-hamburkan (hartamu) secara boros." [Al-Isra' (17):26].

Oleh karena itu melakukan kontrol konsumsi dan pola makanan bagi umat Islam tidak hanya akan bermanfaat dalam mencegah berbagai penyakit degeneratif, tetapi juga bernilai ibadah di sisi-Nya. Oleh karena itu amat beruntunglah orang-orang yang mau melakukan pengaturan konsumsi makanan. Bahkan lebih tegas lagi, Allah SWT menegaskan bahwa berbuat boros atau berlebih-lebihan itu benarbenar suatu hal yang dilarang dan bahkan dianggap sebagi perbuatan yang teramat jahat (saudara setan), seperti yang dijelaskan dalam surah Al-Isra' (17):27.

"Sesungguhnya pemboros-pemboros itu adalah saudara-saudara syaitan dan syaitan itu adalah sangat ingkar kepada Tuhannya." [Al-Isra' (17):27].

\section{Kesimpulan}

Proses degenerasi ini adalah suatu proses yang sejalan dengan meningkatnya umur yang seharusnya diwaspadai, sebagaimana yang diterangkan dalam Al-Qur`an surah AlHajj (22):5, Ar-Ruum (30):54 dan Yaasin (36):68. Dalam ayat ini secara dikatakan bahwa suatu saat sebahagian manusia akan kembali menjadi lemah atau terjadi kemunduran fungsi tubuh seperti ia dahulu kala (degenerasi).
Akan tetapi, tidaklah semua orang bisa jatuh pada penurunan fungsi yang hebat atau menderita penyakit degeneratif.

Berdasarkan kajian ilmu kedokteran, dari tiga kelompok penyakit yang telah diuraikan pada tulisan ini (penyakit kardiovaskuler obesitas dan diabetes melitus) terlihat peranan pengaturan pola konsumsi makanan sangat besar dalam pencegahannya.

Penyakit-penyakit kardiovaskuler sangat erat kaitannya dengan proses aterosklerosis, dan hal ini dipermudah terjadinya oleh kelebihan dan gangguan keseimbangan lemak darah serta kelebihan kolesterol. Gangguan keseimbangan lemak darah (dislipidemia) dan kelebihan kolestrol (hiperkolestrolemia) sangat erat kaitannya dengan konsumsi lemak yang berlebihan.

Obesitas dan diabetes melitus juga sangat erat kaitannya dengan pola konsumsi makanan yang tidak seimbang. Kelebihan kalori dan lemak tinggi menjadi salah satu pemicu terjadinya kelainan-kelainan ini.

Semua kajian dalam ilmu kedokteran ini adalah merupakan pembuktian dari firman Allah SWT yang tercantum dalam Al-Qur`an. Allah SWT dalam surah Al-Isra' (17):26-27 dan Al-A'raf (7):31 telah memberikan tuntunan bahwa pola mengkonsumsi makanan yang diperintahkan adalah secara seimbang dan secukupnya sesuai kebutuhan tubuh dan tidak berlebih-lebihan. Telah nyatalah kebenaran firman Tuhan ini, konsumsi pola dan jenis makanan yang tidak seimbang mendatangkan bahaya diantaranya adalah berbagai macam penyakit degeneratif. Dalam Al-Qur'an dinyatakan bahwa pengaturan pola dan jenis makanan harus mencakup dan memenuhi dua syarat utama, yakni 
aspek hukum (halal) secara syariah yang tegas dan aspek kandungan kebaikan zat nya (tayyiban) [AlBaqarah (2):168-172]. Tayyiban dalam makna luas dapat berarti harus sesuai dengan kebutuhan, tidak berlebihan dan tidak membahayakan tubuh.

\section{KEPUSTAKAAN}

1. Al-Qur'an dan terjemahannya, Departemen Agama RI, Jakarta.

2. Baras F. Mencegah Serangan Jantung dengan Menekan Kolesterol. Jakarta, Gramedia, 1994.

3. Cameron AJ, Welborn TA, Zimmet DZ, Dunotan DW, Owen N, Salmon J. Overweight and obesity in Australia: The 1999-2000 Australian diabetes, obesity and life style study (AusDiab). The Medical Journal of Australia (MJA) 2003; 175: 472-432.

4. Malik AM. Perubahan Pola Hidup dan Kebiasaan Makan Merupakan Faktor Penting Peningkatan Prevalensi Penyakit Kronis. Lokakarya Nasional, Jakarta, 306 Desember 1990.

5. Meilani K. Efek asam lemak tak jenuh omega-3 dalam upaya pencegahan aterosklerosis. Ebers Papyrus 1998; 4(2): 93-104.

6. Rahardja ME. Gizi dan kesehatan jantung koroner. Ebers Papyrus 1996; 2(4): 239-246.

7. Sitopoe M. Kolesterol Fobia dan Kaitannya dengan Penyakit Jantung. Jakarta, Gramedia, 1993.

8. Suyono S. Hiperlipidemia. Dalam Buku Ajar Ilmu Penyakit Dalam, Jilid I, Edisi III. Jakarta, PAPDI, 1996: 714-724.
9. Silberberg JS. Cholesterol lowering and mortality. Medical Progress 1993; 20(2): 9-11.

10. O'Dea JA. Prevention of child obesity; 'first do no harm. Heath Education Research 2005; 20(2): 259-265.

11. Batch JA, Baur LA. Management and prevention of obesity. The Medical Journal of Australia (MJA) 2005; 182(3): 130-135.

12. Proietto J, Baur LA. Management obesity', The Medical Journal of Australia (MJA) 2004; 179(1): 63-64.

13. Margary AM, Daniels LA, Boulton TDJ. Prevalence of overweight and obesity in Australian children and adolescence: Reassessment of 1985 and 1995 data giants new standard international definition. The Medical Journal of Australia (MJA) 2001; 175: 561-564.

14. Suyono S. Masalah Diabetes di Indonesia. Dalam Buku Ajar Ilmu Penyakit Dalam, Jilid I, Edisi III. Jakarta, PAPDI, 1996: 571-585.

15. Darmono. Diagnosis dan klasifikasi diabetes mellitus. Dalam Buku Ajar Ilmu Penyakit Dalam, Jilid I, ed.III. Jakarta, PAPDI, 1996: 590-596.

16. Susman JL, Helseth LD. Reducing the complication of type II diabetes: a patient centered approach. American Family Physician 1997; 56(2): 471478. 